but in Palaotherium there is a gradual diminution of size from $p 4$ to $p 2$, and a sudden one in $p 1$. In Tapirus, $p 3, p 2$, and $p 1$ of the upper jaw progressively depart from the true molar type, as well as diminish in size.

Richard OWen.

\title{
PERMIAN STRATA IN THE VALE OF CLWYD.
}

To the Editor of the Geological Magazine.

Dear Sir,-The letter from Mr. Davies in your last number compels me to again trespass on your space, with a little further explanation of the evidence upon which I premised the existence of Permian strata in the Vale of Clwyd, and the erosion of the Carboniferous rocks before their deposition.

I fully agree with most of the generalisations expressed in the early part of Mr, Davies's letters, and I can assure him that the points he mentions had not escaped me in weighing the evidence bearing on the age of the strata at Pentre Celyn.

When strata become either entirely 'thinned out,' or reduced in thickness by causes connected with their deposition, the reduction in their bulk rarely takes place abruptly, but generally by a somewhat regular rate of diminution. For instance, if a particular formation diminishes to half its thickness in a given distance, say 20 miles, it will only have lost one fourth of its thickness in half the distance.

The Lower Carboniferous rocks in North Wales and the west of England are remarkably consistent in this respect over a very large area; and there is perliaps no class of evidence which more conclusively proves that the various separate masses and ontliers of Carboniferous Limestone and Millstone Grit once formed an unbroken and connected deposit, than the regularity with which their thickness diminishes both from the $\mathrm{NW}$. and $\mathrm{SW}$. towards the middle of England. In the north-west of Wales the Carboniferous Limestone attains a thickness of at least 800 feet. At Llanymynech, on the borders of Shropshire, its thickness is reduced to about half; and following the same rate of diminution in a south-easterly direction, the Limestone is only 30 or 40 feet thick round the flanks of the Wrekin, and becomes entirely lost under the Shropshire Coal-field.

The same regularity of diminution is observable from the SW., where by regular steps it becomes reduced in bulk from the great mass underlying the Bristol and South Wales Coal-fields, through Farlow in the 6W. of Shropshire (where it is considerably diminished) until it thins out to nothing in Shropshire and Staffordshire.

The Mountain Limestone, overlain by a great mass of Millstone Grit, occurs but a few miles to the east of Pentre Celyn. Exposed as bold escarpments, and about two miles to the north, a small outlier of the Millstone Grit crops up in the vale.

At Pentre Celyn no Millstone Grit occurs, and the limestone is unusually thin. Now, as the absence of the Millstone Grit at this point, on the theory of 'thinning out,' is entirely inconsistent with its general uniformity in North Wales, or any rate of diminution at 
which its thickness varies, is it not more probable that the same denudation which has produced in North Wales the numerous escarpments of Lower Carboniferous rocks, has also cleared away the Millstone Grit and part of the Limestone at Pentre Celyn?

It did occur to me that the Pentre Celyn marls and shales might be some part of the Coal Measures; but, on the other hand, it appeared less likely that a break should oceur (implied by the erosion of the Millstone Grit) between the Coal Measures and the Lower Carboniferous rocks, than between the Permian and the Carboniferous series; and the close mineralogical resemblance of the strata at Pentre Celyn to the Permians in other localities seemed to warrant the conclusion expressed in my letter to the Magazine.

Since it was published, I have again visited Pentre Celyn, and was fortunate in meeting with a number of plant impressions in the marly shales found in Mr. Edward's pits. Mr. Etheridge has kindly examined them for me, and states 'they are Permian or Lower New Red species, differing in all respects from Carboniferous.' The fact is interesting, not only as atfurding evidence of a great erosion of the Carboniferous rocks before the deposition of the Permians, but as illustrating the possibility of the conformity of strata separated by an interval of denudation.

Similar strata to those at Pentre Celyn interrene between the Bunter Sandstone and Carboniferous Limestone in several localities along the east side of the vale of Clryd, as in the wood above Llandibr Farm (between Llandibr and Llangynhapal) and at Rhiw Bibbil, opposite Denbigh, \&c. Is it possible that the beds $\mathrm{Mr}$. Davies noticed crossing upon the western side of the vale, between the Limestone and the Sandstone in the cuttings of the Rhyl and Denbigh Railway, and supposed by him to be Coal measures, were Permian, similar to the strata on the east side of the vale of Clwyd? -I remain, dear Sir, very truly yours, Geonge Maw.

Bexthall Hati, Broselex, Oct. 7, 1865.

\section{GLACIAL STRLE IN THE COUNTY OF LONGFORD.}

To the Editor of the Grological Magazine.

Sin,-In the last number of the Gkological Magazive there was an illustrated paper by $\mathrm{Mr}$. A. H. Green, describing some supposed ice-scratches on a Limestone rock in Derbyshire. Mr. Green states that the Limestone is 'studded with dark red patches of chert, which have been polished down to a smooth surface, and scored over with grooves and seratches.'

A similar instance occurs in Co. Longford, Ireland. On the northern slope of Slievegalry (a hill some five miles SSE. of Longford town, and 650 feet above the sea), there is a considerable exposure of Conglomerate (Old Red), dipping $\mathbf{N} 30 \mathrm{~W}$ at about $8^{\circ}$. It consists of numerous pebbles and small boulders of quartz, and occasionally jasper, firmly cemented together in a base of coarse yellowish or reddish white sand.

The pebbles have been worn and polished down to a tlat surface, 